\title{
Intraperitoneal administration of an adenovirus vector carrying REIC/Dkk-3 suppresses peritoneal dissemination of scirrhous gastric carcinoma
}

\author{
SWE SWE THAN ${ }^{1}$, KEN KATAOKA ${ }^{1}$, MASAKIYO SAKAGUCHI ${ }^{1}$, HITOSHI MURATA ${ }^{1}$, \\ FERNANDO ABARZUA ${ }^{1,2}$, CHIKA TAKETA ${ }^{1}$, GANG DU $^{1}$, MASAKAZU YASHIRO ${ }^{3}$, \\ KAZUYOSHI YANAGIHARA ${ }^{4}$, YASUTOMO NASU ${ }^{2}$, HIROMI KUMON ${ }^{2}$ and NAM-HO HUH ${ }^{1}$
}

\begin{abstract}
Departments of ${ }^{1}$ Cell Biology and ${ }^{2}$ Urology, Okayama University Graduate School of Medicine, Dentistry and Pharmaceutical Sciences, 2-5-1 Shikatacho, Kita-ku, Okayama 700-8558; ${ }^{3}$ Department of Surgical Oncology, Osaka City University Graduate School of Medicine, 1-4-3 Asahimachi, Abeno-ku, Osaka 545-8585; ${ }^{4}$ Department of Life Sciences, Yasuda Women's University Faculty of Pharmacy, 6-13-1 Yasuhigashi, Asaminami-ku, Hiroshima 731-0153, Japan
\end{abstract}

Received November 11, 2010; Accepted December 9, 2010

DOI: $10.3892 /$ or.2011.1149

\begin{abstract}
Expression levels of the novel tumor suppressor gene REIC/Dkk-3 are reduced in many human cancers. We have previously showed that an adenovirus vector carrying REIC/Dkk-3 (Ad-REIC) induced apoptosis of cancer cells selectively and exerted bystander antitumor effects via ER stress. We examined possible effects of Ad-REIC in a peritoneal dissemination model of scirrhous gastric carcinoma (SGC). Among various types of gastric cancer, SGC continues to be associated with the worst prognosis due to a high incidence of metastases in the peritoneal cavity. We found that a single intraperitoneal injection of Ad-REIC suppressed tumor dissemination and disease progression. Immunomodulation by Ad-REIC led to recruitment of natural killer cells inside tumor nodules. We conclude that Ad-REIC gene therapy may be a potential tool in combinatorial approaches to achieve curative effects in SGC.
\end{abstract}

\section{Introduction}

Gastric cancer is the second leading cause of cancer death in men and the fourth in women in the world. The five-year survival rate in the United States and Europe is $>25 \%$ (1). Among various types of gastric cancer, scirrhous gastric carcinoma (SGC) remains to be associated with the worst prognosis due to a high incidence of metastasis in the peritoneal

Correspondence to: Dr Ken Kataoka, Department of Cell Biology, Okayama University Graduate School of Medicine, Dentistry and Pharmaceutical Sciences, 2-5-1 Shikatacho, Kita-ku, Okayama 700-8558, Japan

E-mail: kenk@md.okayama-u.ac.jp

Key words: REIC/Dkk-3, scirrhous gastric carcinoma, gene therapy cavity. The five-year survival rate is $0-17 \%$ for SGC compared with $35-70 \%$ for other gastric carcinomas in Japan (2). Peritoneal metastasis is a critical limiting condition for the choice of treatment options to prolong patient survival. Once it occurs, most patients become inoperable.

Impairment of the immune surveillance system is known to contribute to cancer progression. Takeuchi et al (3) reported that activity of natural killer (NK) cells in gastric cancer patients was diminished and that there was a significant link between NK cell activity and tumor size. Tumor volume and dissemination were also affected by NK cell activity. Multimodal approaches using surgery and supportive therapies such as chemotherapy, radiotherapy, hormonal therapy and immunotherapy have been attempted. However, these combination therapies have not resulted in considerable improvement in the survival rate of SGC patients (4). Thus, development of new therapeutic tools to prevent or at least to suppress peritoneal metastasis is important for patients with SGC. The most critical challenge of SGC is dissemination in the peritoneal cavity, which results in formation of multiple cancer nodules. This precludes surgical removal of tumors and radiation therapy. Gene therapy therefore has a potential advantage since gene therapeutic agents can be applied directly into the peritoneal cavity.

We previously demonstrated that the tumor suppressor gene REIC/Dkk-3 was down-regulated in a number of human cancer cell lines (5). Overexpression of REIC/Dkk-3 gene using an adenovirus vector (Ad-REIC) had a dramatic therapeutic effect on human renal cell carcinoma (6), prostate cancer (7), breast cancer (8), testicular cancer (9) and pleural mesothelioma (10). Ad-REIC induced apoptotic cell death through activation of c-Jun N-terminal kinase (7-10). In addition, we have recently shown that Ad-REIC has a hostmediated bystander effect on human prostate cancer through IL-7 induction (11).

In the present study, we examined whether intraperitoneally administered Ad-REIC is effective for suppressing growth and dissemination of human SGC cells in a mouse model. 

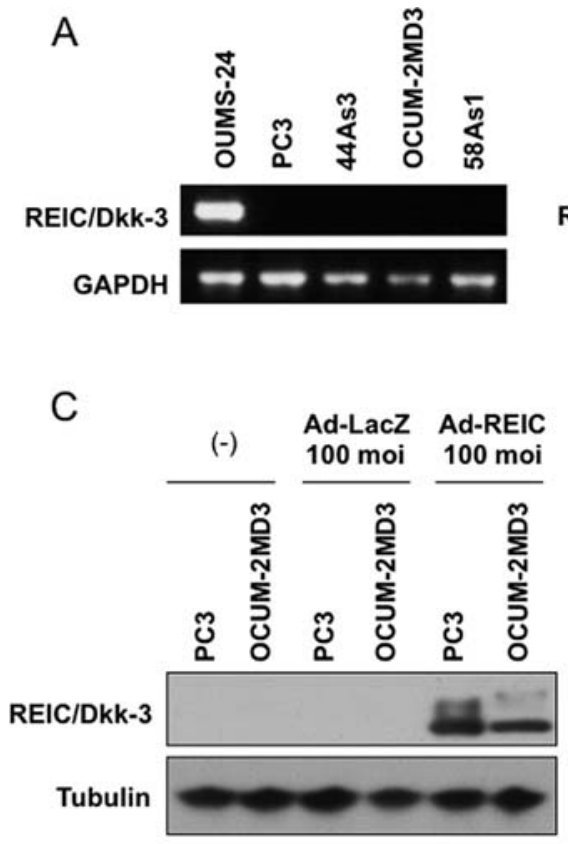
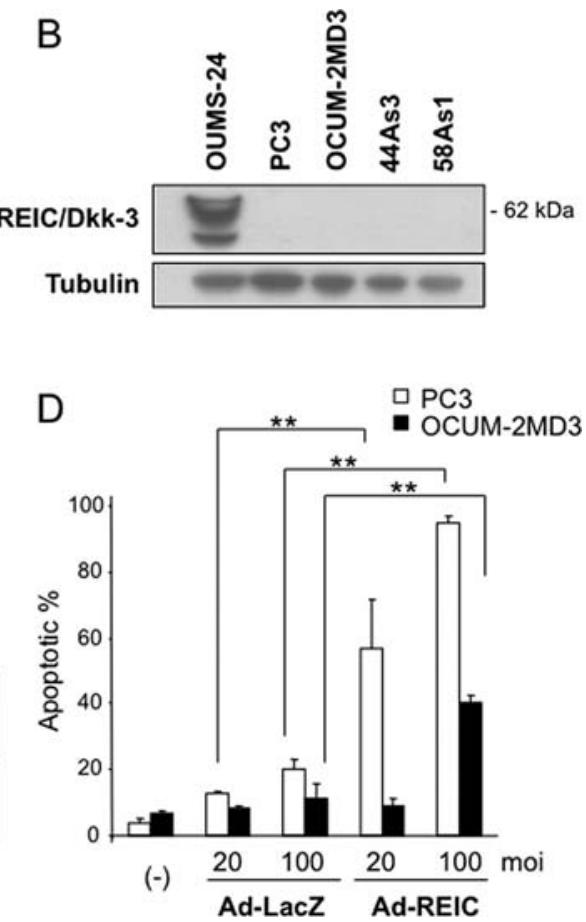

Figure 1. Expression of endogenous REIC/Dkk-3 in SGCs and induction of apoptosis by Ad-REIC in culture. (A) RT-PCR for REIC/Dkk-3 in SGCs (44As3, OUCUM-2MD3 and 58As1). Normal human fibroblasts (OUMS-24) and human prostate carcinoma cells (PC3) were used as positive and negative controls, respectively. (B) Endogenous REIC/Dkk-3 protein levels determined by Western blot analysis. (C) Over-expression of REIC/Dkk-3 in OCUM-2MD3 cells and PC3 cells infected with Ad-REIC or Ad-LacZ at 100 moi. (D) Induction of apoptosis by Ad-REIC in culture. Seventy-two hours after infection, apoptotic cells were determined. White column, PC3 cells; black column, OUCUM-2MD3 cells. Bars show mean \pm SD. ${ }^{* *} \mathrm{P}<0.01$ by Student's t-test.

\section{Materials and methods}

Animals. Female BALB/c nude mice at the age of 6-8 weeks were purchased from Charles River (Yokohama, Japan). All of the experiments were conducted in accordance with the guidelines for animal experiments of our institution.

Cell lines. A human scirrhous gastric cancer cell line, OCUM2MD3 (12), and a prostate cancer cell line, PC3 (provided by American Type Culture Collection, Rockville, MD), were cultured in DMEM/F12 (Ham) (1:1) (Invitrogen, Carlsbad, CA). Scirrhous gastric cancer cell lines, 44As3 and 58As1 (13) were cultured in RPMI-1640 (Nissui, Tokyo, Japan). A normal human fibroblast cell line, OUMS-24 (14), was cultured in DMEM (Nissui). All media were supplemented with $10 \%$ fetal bovine serum (Invitrogen), $100 \mu \mathrm{g} / \mathrm{ml}$ kanamycin (Meiji Seika, Tokyo, Japan) and $0.5 \mu \mathrm{g} / \mathrm{ml}$ Fungizone (Invitrogen).

Adenovirus vectors. Ad-REIC was produced and propagated as described previously (7). An adenovirus vector carrying the LacZ gene (Ad-LacZ) was used for monitoring infection efficiency.

$R T$-PCR analysis. To extract total RNA, cells were processed by the acid guanidinium-phenol-chloroform method using TRI reagent (Sigma, St. Louis, MO). RT-PCR was performed under conventional conditions. The primers used were as follows: human REIC/Dkk-3 (forward) 5'-CAGTTA TCACATCTGTGGGAGACGAA-3', human REIC/Dkk-3 (reverse) 5'-AACTTCATACTCATCGGGGACCTCT-3', glyceraldehydes-3-phosphate dehydrogenase (GAPDH: forward) 5'-GGGTGTGAACCATGAGAAGTATGA-3', GAPDH (reverse) 5'-TGCTAAGCAGTTGGTGGTGC-3'.

Western blot analysis. Western blot analysis was performed under conventional conditions. The antibodies used were as follows: rabbit anti-human REIC/Dkk-3 antibody raised in our laboratory, mouse anti-human tubulin antibody (Sigma), and horseradish peroxidase-conjugated anti-mouse or antirabbit IgG antibody (Cell Signaling Technology, Danvers, MA) as the second antibody.

Apoptosis assay. Cells were inoculated into flat-bottom 6-well plates and incubated for $24 \mathrm{~h}$ and then treated with Ad-LacZ or Ad-REIC at the indicated multiplicity of infection (moi). Seventy-two hours later, $1 \mu \mathrm{g} / \mathrm{ml}$ Hoechst 33342 (Invitrogen) and $5 \mu \mathrm{g} / \mathrm{ml}$ propidium iodide (Sigma) were added to the medium. Then the cells were incubated in the dark for $20 \mathrm{~min}$. All of the cells were collected on a glass slide. Under a fluorescent microscope, cells with fragmented or shrunken nuclei were counted as apoptotic cells.

Intraperitoneal administration of Ad-REIC in a peritoneal dissemination model of SGC. OCUM-2MD3 cells ( $1 \times 10^{7}$ cells in $200 \mu \mathrm{l}$ PBS) were injected into the peritoneal cavity of female BALB/c nude mice at the age of 6-8 weeks. Twentyfour hours later, the mice were intraperitoneally injected with $4 \mathrm{ml}$ PBS, $1 \times 10^{9}$ plaque-forming units (p.f.u.) Ad-LacZ in $4 \mathrm{ml}$ PBS, or $1 \times 10^{9}$ p.f.u. Ad-REIC in $4 \mathrm{ml}$ PBS. At different time points, mice were sacrificed and peritoneally disseminated cancer nodules were collected. The number of peritoneal nodules $>1 \mathrm{~mm}$ in diameter was counted macroscopically. Cancer nodules were classified according to the longest 

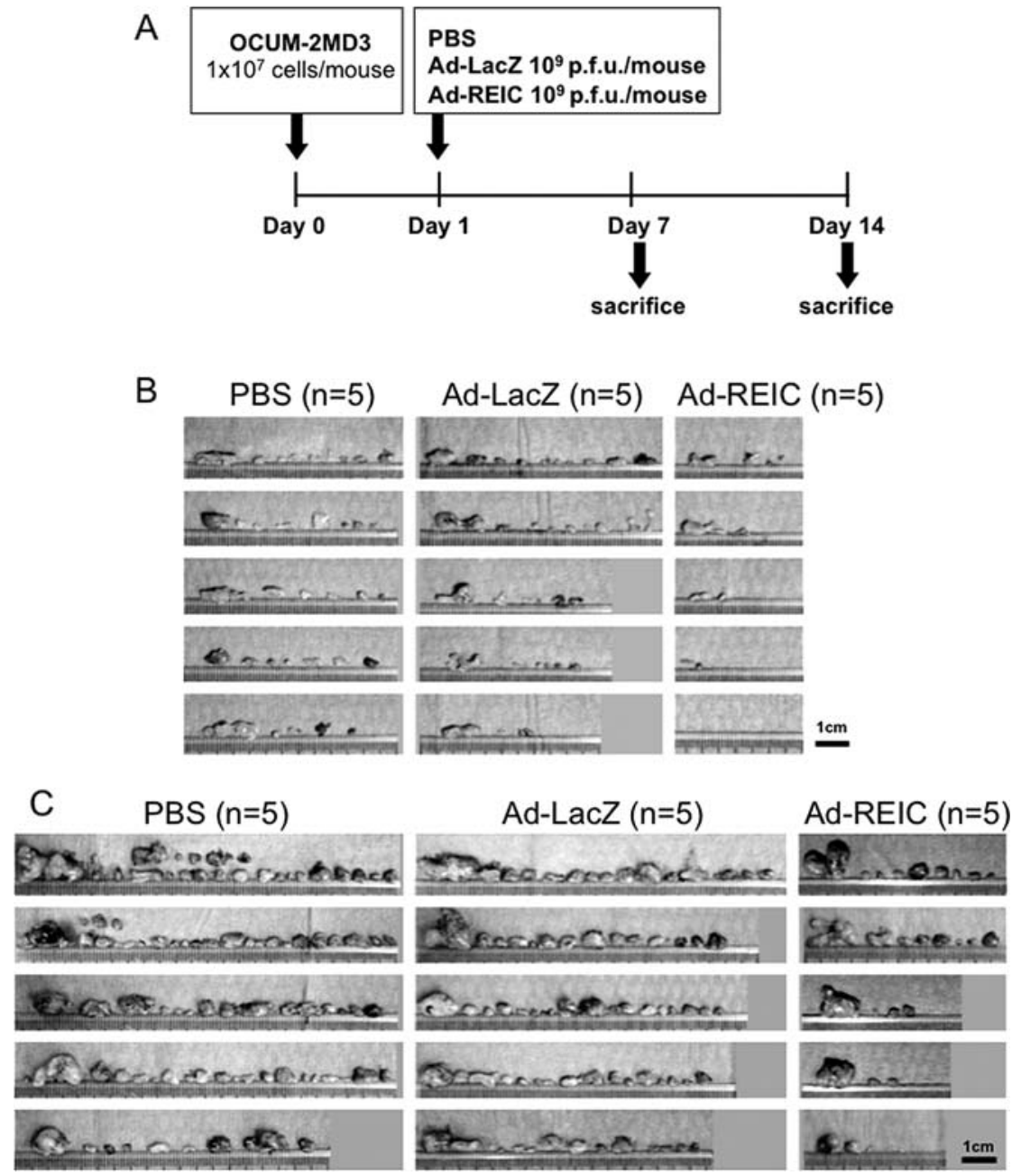

Figure 2. Inhibition of dissemination and growth of OCUM-2MD3 cells by Ad-REIC in a peritoneal dissemination mouse model. (A) Protocol of the experiment. The mice were sacrificed and all cancer nodules appreciable with the naked eye in the peritoneal cavity were collected on day 7 (B) and day 14 (C). Bars, $1 \mathrm{~cm}$.

diameter $(<3,<3-5$ and $>5 \mathrm{~mm})$. Tumor volume was calculated using an empirical formula, $\mathrm{V}=1 / 2 \mathrm{x}$ (shortest diameter) ${ }^{2} \mathrm{x}$ (longest diameter). To examine the regional distribution of cancer nodules in the peritoneal cavity, the number of mice with at least one nodule in a given region was counted in each group.

Immunohistochemical staining. Collected tissues were fixed in $10 \%$ neutral-buffered formalin overnight. Paraffin sections of $6 \mu \mathrm{m}$ in thickness were prepared. Terminal deoxy-nucleotidyltransferase-mediated UTP end-labeling (TUNEL) assay was performed using In situ Cell Death detection kit Fluorescein (Roche, Basel, Switzerland). Tissue sections were immunostained with Fluorescein isothiocyanateconjugated rat anti-mouse CD49b antibody (Miltenyi Biotec, Auburn, CA) for identification of mouse NK cells under the conditions described previously (11).

\section{Results}

In vitro effect of Ad-REIC/Dkk-3 on human scirrhous gastric cancer cell lines. We first examined the endogenous expression level of REIC/Dkk-3 in human SGC cell lines (OCUM2MD3, 44As3 and 58As1). Both mRNA and protein levels of
REIC/Dkk-3 were down-regulated in scirrhous gastric cancer cells (Fig. 1A and B). Normal human fibroblasts (OUMS-24) expressed REIC/Dkk-3 protein with different molecular sizes due to differential glycosylation (Fig. 1B). Infection efficiency of the adenovirus vector in OCUM-2MD3 cells was $95 \%$ at 20 moi (data not shown). The expression level of REIC/Dkk-3 after infection of OCUM-2MD3 cells with Ad-REIC was similar to that of PC3 cells (Fig. 1C).

Apoptotic rates of OCUM-2MD3 cells determined at $72 \mathrm{~h}$ after infection with Ad-REIC were 10 and $41 \%$ at the moi of 20 and moi of 100, respectively (Fig. 1D). Rates of Ad-REICinduced apoptosis of PC3 cells, which are known to be sensitive to Ad-REIC, were 56 and $95 \%$ at 20 and 100 moi, respectively (Fig.1D). Thus, OCUM-2MD3 cells showed limited sensitivity to induction of apoptosis by Ad-REIC in culture.

Intraperitoneal administration of Ad-REIC suppresses dissemination and growth of SGC cells. To explore the therapeutic efficacy of REIC/Dkk-3 gene transfer into the peritoneal cavity, OCUM-2MD3-inoculated mice were treated on day 1 with a single injection of Ad-REIC ( $10^{9}$ p.f.u./mouse $)$ as shown in Fig. 2A. On days 7 and 14, the mice were sacrificed and tumor nodules were harvested (Fig. $2 \mathrm{~B}$ and C). Ad-REIC- 

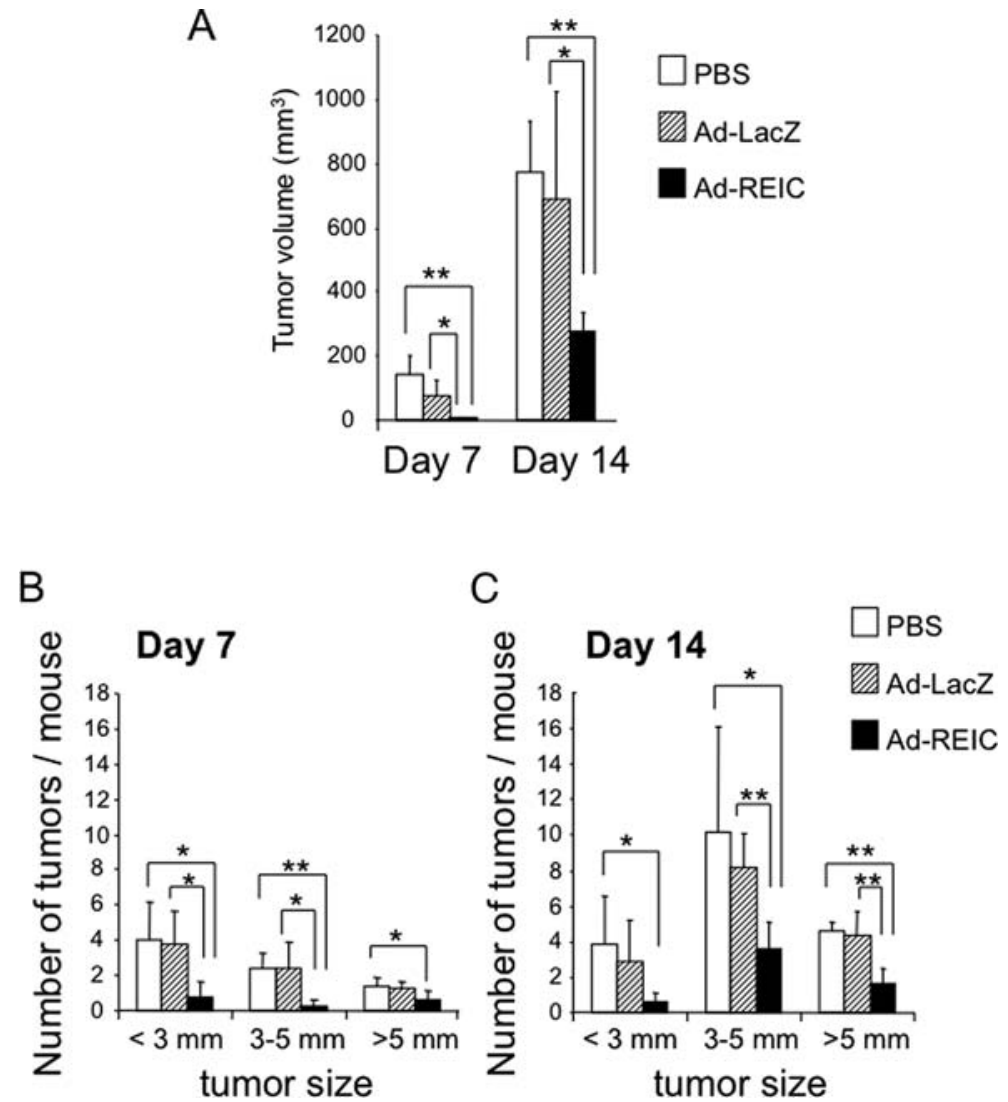

Figure 3. Quantitative analysis of peritoneal nodules of OCUM-2MD3 in mice treated with or without Ad-REIC. (A) Cumulated tumor volume on days 7 and 14. (B) Number of tumors per mouse on day 7 (left) and day 14 (right). Bars show the mean \pm SD. ${ }^{*} \mathrm{P}<0.05,{ }^{* *} \mathrm{P}<0.01$ by Student's t-test.

Table I. Incidence of dissemination in the peritoneal cavity at day $7 .{ }^{\text {a }}$

\begin{tabular}{lccccccc}
\hline & $\begin{array}{c}\text { Sero-bloody/ } \\
\text { bloody ascites }\end{array}$ & $\begin{array}{c}\text { Paragastric } \\
\text { region }\end{array}$ & $\begin{array}{c}\text { Splenic } \\
\text { region }\end{array}$ & Sub-diaphragm & $\begin{array}{c}\text { Kidney } \\
\text { region }\end{array}$ & $\begin{array}{c}\text { Mesentery } \\
\text { Inguinal } \\
\text { region }\end{array}$ & $\begin{array}{c}\text { Liver } \\
\text { region }\end{array}$ \\
\hline PBS $(\mathrm{n}=5)$ & $0 / 5$ & $5 / 5$ & $5 / 5$ & $4 / 5$ & $1 / 5$ & $1 / 5$ & $1 / 5$ \\
Ad-LacZ $(\mathrm{n}=5)$ & $0 / 5$ & $5 / 5$ & $4 / 5$ & $3 / 5$ & $3 / 5$ & $1 / 5$ & $0 / 5$ \\
Ad-REIC $(\mathrm{n}=5)$ & $0 / 5$ & $3 / 5$ & $1 / 5$ & $0 / 5$ & $0 / 5$ & $0 / 5$ & $0 / 5$ \\
\hline
\end{tabular}

aData are shown as the number of mice bearing at least one tumor $(>1 \mathrm{~mm})$ in each region.

Table II. Incidence of dissemination in the peritoneal cavity at day $14 .^{\mathrm{a}}$

\begin{tabular}{|c|c|c|c|c|c|c|c|c|}
\hline & $\begin{array}{l}\text { Sero-bloody/ } \\
\text { bloody ascites }\end{array}$ & $\begin{array}{c}\text { Paragastric } \\
\text { region }\end{array}$ & $\begin{array}{l}\text { Splenic } \\
\text { region }\end{array}$ & Sub-diaphragm & $\begin{array}{l}\text { Kidney } \\
\text { region }\end{array}$ & Mesentery & $\begin{array}{l}\text { Inguinal } \\
\text { region }\end{array}$ & $\begin{array}{l}\text { Liver } \\
\text { region }\end{array}$ \\
\hline $\operatorname{PBS}(n=5)$ & $5 / 5$ & $5 / 5$ & $5 / 5$ & $5 / 5$ & $5 / 5$ & $5 / 5$ & $5 / 5$ & $0 / 5$ \\
\hline Ad-LacZ (n=5) & $5 / 5$ & $5 / 5$ & $4 / 5$ & $5 / 5$ & $5 / 5$ & $5 / 5$ & $4 / 5$ & $0 / 5$ \\
\hline Ad-REIC $(n=5)$ & $1 / 5$ & $5 / 5$ & $4 / 5$ & $2 / 5$ & $3 / 5$ & $1 / 5$ & $1 / 5$ & $1 / 5$ \\
\hline
\end{tabular}

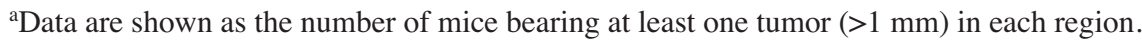

treated mice on day 7 showed significantly lower tumor volume than did PBS or Ad-LacZ-treated mice. This trend was observed partially on day 14 (Fig. 3A).
On day 7, a significant tumor suppressive effect of AdREIC was obvious in smaller tumors of $>5 \mathrm{~mm}$ (Fig. 3B). As shown in Table I, tumor incidence in Ad-REIC-treated mice 
$\mathrm{PI}$
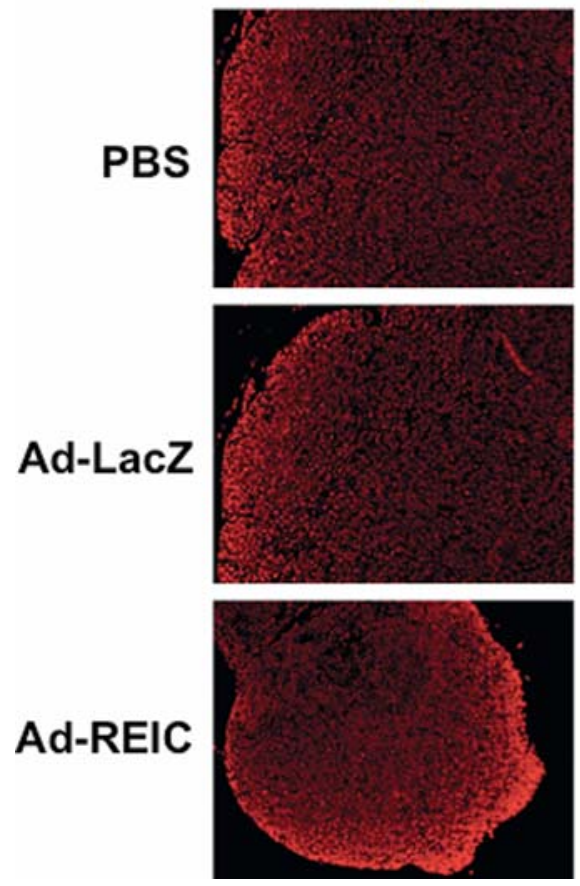

TUNEL
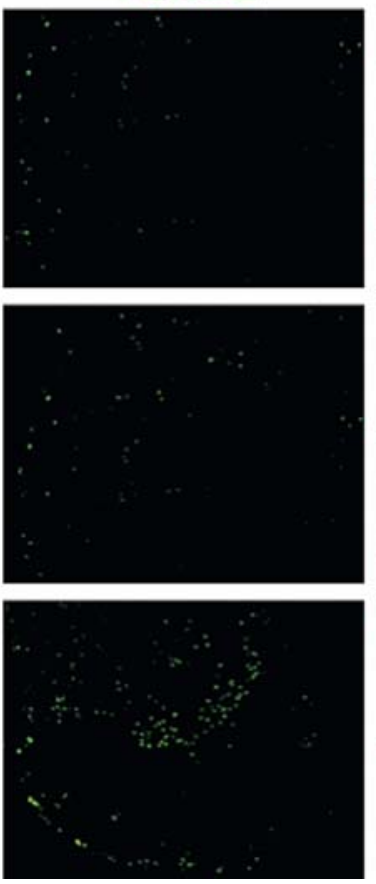

PI/ TUNEL
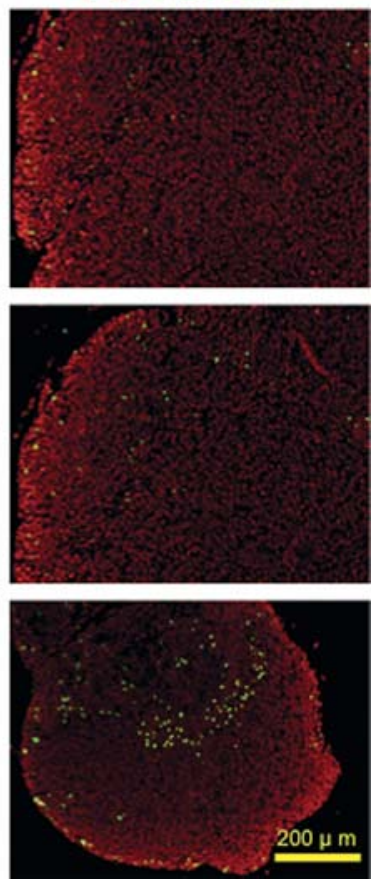

Figure 4. Induction of apoptosis detected by TUNEL staining in tumor nodules examined on day 7. Bars, $200 \mu \mathrm{m}$.

$\mathrm{Pl}$

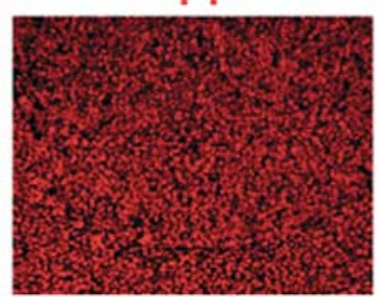

PBS

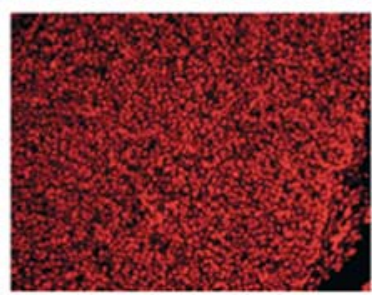

Ad-LacZ

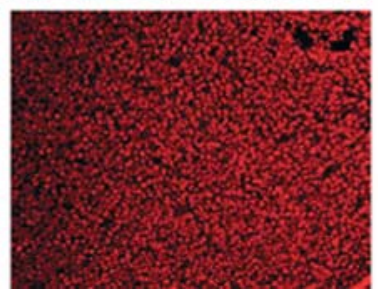

CD49b
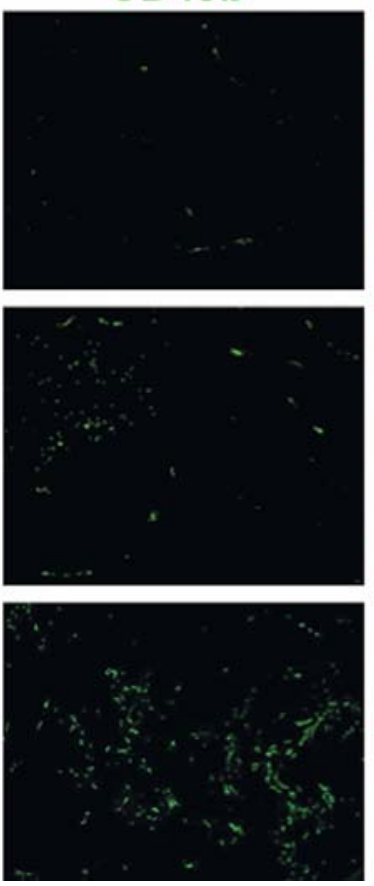

$\mathrm{Pl} / \mathrm{CD} 49 \mathrm{~b}$
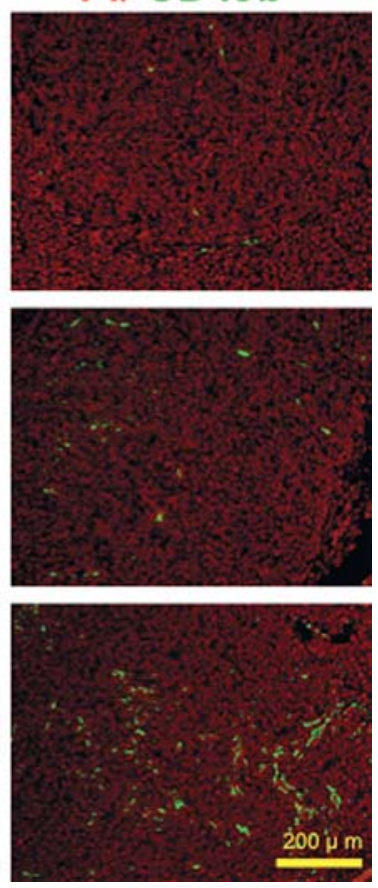

Figure 5. Infiltration of NK cells detected by the specific marker CD49b in tumor nodules examined on day 7. Bars, $200 \mu \mathrm{m}$.

was reduced particularly in splenic and subdiaphragmatic regions. Compared to the controls, dissemination to the paragastric or kidney region was also limited.

The average number of moderately sized (3-5 mm) tumors obtained from Ad-REIC-treated mice increased from day 7 to day 14 (Fig. 3B and C). However, this average number was still significantly less than that of the controls on day 14 (Fig. 3C). Additionally, as shown in Table II, there was a low incidence of tumors in mesentery, subdiaphragm, kidney and inguinal regions. Accumulation of sero-bloody or bloody ascites was also remarkably suppressed in Ad-REIC-treated mice.

Ad-REIC enhances recruitment of NK cells and apoptosis in tumor tissues. Immunohistochemical staining demonstrated TUNEL-positive cells inside tumor tissues of Ad-REIC-treated mice on day 7 (Fig. 4). In addition to the tumor suppressive 


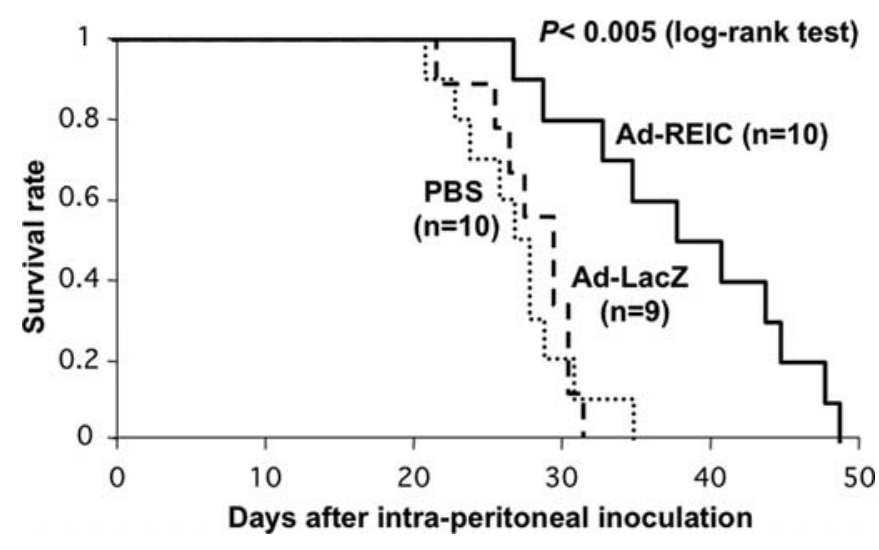

Figure 6. The mean survival time of OCUM-2MD3-transplanted mice treated with Ad-REIC. Kaplan-Meyer analysis was applied for Ad-REICtreated mice $(n=10)$, Ad-LacZ-treated mice $(n=9)$, and PBS-treated mice $(n=10) . P<0.005$ by $\log$-rank test.

effect of Ad-REIC, NK cells were observed in tumor tissues harvested from Ad-REIC-treated mice on day 7. These NK cells expressed the NK cell-specific marker CD49b (Fig. 5). This result indicates that Ad-REIC activated peritoneal immune cells in BALB/c nude mice.

Intraperitoneal administration of Ad-REIC prolonged survival in an SGC dissemination mouse model. To evaluate the overall effect of Ad-REIC administration in an SGC dissemination mouse model, we observed the survival period after treatment. Intraperitoneal inoculation of OCUM-2MD3 cells resulted in the formation of sero-bloody or bloody peritoneal ascites and tumor nodules in almost all peritoneal regions (Table II), and all of the mice died within four weeks (mean survival period: 27.2 days). The mean survival period of Ad-LacZ-treated control mice was 28.5 days. However, the survival period was significantly prolonged in Ad-REICtreated mice (mean period of 39 days) (Fig. 6).

\section{Discussion}

We previously demonstrated that Ad-REIC showed growthsuppressive and apoptosis-inducing effects on human cancers derived from the prostate, testis, pleura and breast (6-10). The induction of apoptosis was observed selectively in cancer cells and normal cells were marginally affected $(7,9)$. When applied onto SGC, Ad-REIC efficiently infected and produced REIC/Dkk-3 protein (Fig. 1C). The rate of cell apoptosis induced by Ad-REIC at 100 moi was $41 \%$ after $72 \mathrm{~h}$ exposure in culture. The titer of Ad-REIC was high enough to induce $\sim 95 \%$ apoptosis in PC3 cells (Fig. 1D). This means that the sensitivity of OCUM-2MD3 cells to induction of apoptosis by Ad-REIC is limited. On the other hand, our present data showed that application of Ad-REIC in vivo resulted in suppression of dissemination/growth of OCUM2MD3 cells and prolongation of survival.

To date, there have been few reports on adenovirusmediated gene therapy for peritoneally disseminated SGC. Tanaka et al (15) reported that multiple injections of an adenovirus carrying ICAM-2 gene to mice with peritoneally disseminated SGC resulted in reduction of peritoneal dissemination through activation of NK cells. In the present study, a single injection of Ad-REIC recruited NK cells to peritoneal tumors in BALB/c nude mice (Fig. 5). This is consistent with results of our previous study showing that Ad-REIC has a capacity to activate NK cells (11). The activation was due to induction of IL-7, which was triggered by ER stress caused by overproduction of REIC/Dkk-3 protein. NK cells have a direct cytotoxic effect against a broad range of human solid tumors and virus-infected target cells in the absence of the major histocompatibility complex on their target cells $(3,16)$. In Ad-REIC-treated mice, TUNEL-positive apoptotic cells were observed inside the peritoneal tumor nodules (Fig. 4). Takeuchi et al (3) showed that NK cell activity inversely correlated with tumor size in gastric cancer patients. It is known that athymic nude mice have higher cytotoxic activity of NK cells and macrophages than that in their euthymic counterparts (17). We previously showed that intratumoral injection of REIC/Dkk-3 protein enhanced recruitment of CD11 $\mathrm{c}^{+}$monocytes to tumor nodules (18). Thus, application of Ad-REIC probably resulted in activation of the host immune system by synergistic mechanisms of ER stresstriggered induction of IL-7 and a physiological function of secreted REIC/Dkk-3 protein.

Peritoneal mesothelial cells (PMCs) cover the surfaces of internal organs in the peritoneal cavity and the peritoneal wall. Human PMCs have a capacity to produce large amounts of cytokines, including interleukin (IL)-1, IL-6, IL-8, granulocyte colony-stimulation factor and vascular endothelial growth factor (19-22). PMCs are thought to affect peritoneal metastasis of various human cancers. As we showed previously (11), infection of normal cells with Ad-REIC resulted in activation of the immune system. Engler et al (23) reported that transgene expression was higher in the peritoneal wall than in tumor tissue when Ad-LacZ was injected into the abdominal cavity of nude mice bearing PC3 prostate cancer. In our study, both tumor tissues and the peritoneum were infected with Ad-LacZ as examined 4 days after injection (data not shown). Infection of both normal and malignant cells in the peritoneal cavity with Ad-REIC probably resulted in production of various cytokines and eventual activation of the host immune system.

Intraperitoneal administration of Ad-REIC suppressed peritoneal dissemination of OCUM-2MD3 cells and prolonged the survival of cancer-bearing mice. However, Ad-REIC treatment alone was not sufficient to achieve high therapeutic efficacy in the peritoneal dissemination model of SGC we used. A challenge to explore the possibility of augmenting anticancer activity of REIC/Dkk-3 by combining with other therapeutic modalities remains to be pursued.

\section{Acknowledgements}

This study was supported in part by a grant from the Ministry of Education, Culture, Sports, Science, and Technology of Japan (C 21591699) to K. Kataoka.

\section{References}

1. Global Cancer Facts and Figures 2007, American Cancer Society, Atlanta, 2007.

2. Liu Y, Yoshimura K, Yamaguchi N, Shinmura K, Yokota J and Katai H: Causation of Borrmann type 4 gastric cancer: heritable factors or environmental factors? Gastric Cancer 6: 17-23, 2003. 
3. Takeuchi H, Maehara Y, Tokunaga E, Koga T, Kakeji Y and Sugimachi K: Prognostic significance of natural killer cell activity in patients with gastric carcinoma: a multivariate analysis. Am J Gastroenterol 96: 574-578, 2001.

4. Ikeguchi M, Miyake T, Matsunaga T, Yamamoto M, Fukumoto Y, Yamada Y, Fukuda K, Saito H, Tatebe S and Tsujitani S: Recent results of therapy for scirrhous gastric cancer. Surg Today 39: 290-294, 2009.

5. Tsuji T, Miyazaki M, Sakaguchi M, Inoue Y and Namba M: A REIC gene shows down-regulation in human immortalized cells and human tumor-derived cell lines. Biochem Biophys Res Commun 268: 20-24, 2000.

6. Kurose K, Sakaguchi M, Nasu Y, Ebara S, Kaku H, Kariyama R, Arao Y, Miyazaki M, Tsushima T, Namba M, Kumon $H$ and Huh NH: Decreased expression of REIC/Dkk-3 in human renal clear cell carcinoma. J Urol 171: 1314-1318, 2004.

7. Abarzua F, Sakaguchi M, Takaishi M, Nasu Y, Kurose K, Ebara S, Miyazaki M, Namba M, Kumon H and Huh NH: Adenovirusmediated overexpression of REIC/Dkk-3 selectively induces apoptosis in human prostate cancer cells through activation of c-Jun-NH2-kinase. Cancer Res 65: 9617-9622, 2005.

8. Kawasaki K, Watanabe M, Sakaguchi M, Ogasawara Y, Ochiai K, Nasu Y, Doihara H, Kashiwakura Y, Huh NH, Kumon H and Date H: REIC/Dkk-3 overexpression downregulates P-glycoprotein in multidrug-resistant MCF7/ADR cells and induces apoptosis in breast cancer. Cancer Gene Ther 16: 65-72, 2009.

9. Tanimoto R, Abarzua F, Sakaguchi M, Takaishi M, Nasu Y, Kumon $\mathrm{H}$ and Huh NH: REIC/Dkk-3 as a potential gene therapeutic agent against human testicular cancer. Int J Mol Med 19: 363-368, 2007.

10. Kashiwakura Y, Ochiai K, Watanabe M, Abarzua F, Sakaguchi M, Takaoka M, Tanimoto R, Nasu Y, Huh NH and Kumon H: Down-regulation of inhibition of differentiation-1 via activation of activating transcription factor 3 and Smad regulates REIC/ Dickkopf-3-induced apoptosis. Cancer Res 68: 8333-8341, 2008.

11. Sakaguchi M, Kataoka K, Abarzua F, Tanimoto R, Watanabe M, Murata H, Than SS, Kurose K, Kashiwakura Y, Ochiai K, Nasu Y, Kumon H and Huh NH: Overexpression of REIC/Dkk-3 in normal fibroblasts suppresses tumor growth induction of interleukin-7. J Biol Chem 284: 14236-14244, 2009.

12. Yashiro $M$, Chung YS, Nishimura S, Inoue $T$ and Sowa $M$ : Peritoneal metastatic model for human scirrhous gastric carcinoma in nude mice. Clin Exp Metastasis 14: 43-54, 1996.

13. Yanagihara K, Takigahira M, Tanaka H, Komatsu T, Fukumoto $H$, Koizumi F, Nishio K, Ochiya T, Ino Y and Hirohashi S: Development and biological analysis of peritoneal metastasis mouse models for human scirrhous stomach cancer. Cancer Sci 96: 323-332, 2005.
14. Bai L, Mihara K, Kondo Y, Honma M and Namba M: Immortalization of normal human fibroblasts by treatment with 4-nitroquinoline 1-oxide. Int J Cancer 53: 451-456, 1993.

15. Tanaka H, Yashiro M, Sunami T, Sakate Y, Kosaka K and Hirakawa K: ICAM-2 gene therapy for peritoneal dissemination of scirrhous gastric carcinoma. Clin Cancer Res 10: 4885-4892, 2004.

16. Carroll JL, Nielsen LL, Pruett SB and Mathis JM: The role of natural killer cells in adenovirus-mediated p53 gene therapy. Mol Cancer Ther 1: 49-60, 2001.

17. Budzynski W and Radzikowski C: Cytotoxic cells in immunodeficient athymic mice. Immunopharmacol Immunotoxicol 16: 319-346, 1994.

18. Watanabe M, Kashiwakura Y, Huang P, Ochiai K, Futami J, Li SA, Takaoka M, Nasu Y, Sakaguchi M, Huh NH and Kumon H: Immunological aspects of REIC/Dkk-3 in monocyte differentiation and tumor regression. Int J Oncol 34: 657-663, 2009.

19. Topley N, Jörres A, Luttmann W, Petersen MM, Lang MJ, Thierauch KH, Müller C, Coles GA, Davies M and Williams JD: Human peritoneal mesothelial cells synthesize interleukin-6: induction by IL-1 beta and TNF alpha. Kidney Int 43: 226-233, 1993.

20. Lanfrancone L, Boraschi D, Ghiara P, Falini B, Grignani F, Peri G, Mantovani A and Pelicci PG: Human peritoneal mesothelial cells produce many cytokines [granulocyte colony-stimulating factor (CSF), granulocyte-monocyte-CSF, macrophage-CSF, interleukin-1 (IL-1), and IL-6] and are activated and stimulated to grow by IL-1. Blood 80: 2835-2842, 1992.

21. Topley N, Brown Z, Jörres A, Westwick J, Davies M, Coles GA and Williams JD: Human peritoneal mesothelial cells synthesize interleukin-8. Synergistic induction by interleukin-1 beta and tumor necrosis factor-alpha. Am J Pathol 142: 18761886,1993

22. Sako A, Kitayama J, Yamaguchi H, Kaisaki S, Suzuki H, Fukatsu K, Fujii S and Nagawa H: Vascular endothelial growth factor synthesis by human omental mesothelial cells is augmented by fibroblast growth factor-2: possible role of mesothelial cell on the development of peritoneal metastasis. J Surg Res 115: 113-120, 2003.

23. Engler H, Machemer TR, Schluep T, Wen SF, Quijano E, Wills KN, Harper AE, Maneval DC and Conroy SE: Development of a formulation that enhances gene expression and efficacy following intraperitoneal administration in rabbits and mice. Mol Ther 7: 558-564, 2003. 